\title{
ANALYSIS OF ECOTOURISM POTENTIAL OF BOTUTONUO BEACH IN BONE BOLANGO REGENCY, INDONESIA
}

\author{
Sunarty Suly ERAKU \\ Gorontalo State University, Geography Education Study Program, Earth Science and Technology \\ Department, Faculty of Mathematics and Natural Science, Indonesia, e-mail: sunarty.eraku@ung.ac.id
}

\section{Aang Panji PERMANA*}

Gorontalo State University, Geological Engineering Study Program, Earth Science and Technology

Department, Faculty of Mathematics and Natural Science, Indonesia, e-mail: aang@ung.ac.id

\begin{abstract}
Ahmad Syamsu RIJAL
Gorontalo State University, Geography Education Study Program, Earth Science and Technology

Department, Faculty of Mathematics and Natural Science, Indonesia, e-mail: ahmadsyamsurijals@gmail.com
\end{abstract}

\section{Mohamad Karmin BARUADI}

Gorontalo State University, Indonesian Language and Literature Department, Faculty of Letters and Culture, Indonesia, e-mail: karminbaruadi11@gmail.com

\section{HENDRA}

Gorontalo State University, Geography Education Study Program, Earth Science and Technology Department, Faculty of Mathematics and Natural Science, Indonesia, e-mail: hendra@ung.ac.id

\section{Mohamad Noorhidayat BARUADI}

Gorontalo State University, Geological Engineering Study Program, Earth Science and Technology Department, Faculty of Mathematics and Natural Science, Indonesia, e-mail: yayatbaruadi@gmail.com

\begin{abstract}
Citation: Eraku, S.S., Permana, A.P., Rijal, A.S., Baruadi, M.K., Hendra, \& Baruadi, M.N. (2021). ANALYSIS OF ECOTOURISM POTENTIAL OF BOTUTONUO BEACH IN BONE BOLANGO REGENCY, INDONESIA. GeoJournal of Tourism and Geosites, 36(2spl), 624-629. https://doi.org/10.30892/gtg.362spl09-691
\end{abstract}

\begin{abstract}
The ecotourism potential of the beach area in Bone Bolango regency, if developed optimally, is very high. Ecotourism development is a tourism activity that incorporates the principles of environment-friendly attitudes. It emphasizes the aspects of nature conservation, empowerment of the local community's economic, social, and cultural competence, as well as education. Botutonuo beach is among the coastal areas in Bone Bolango regency with high ecotourism potential. The present study aimed to analyze the ecotourism potential of Botutonuo beach based on the physical, sociocultural, economic, and institutional parameters. It employed an ecological-spatial approach by involving the Geographic Information System (GIS). The research method comprised field observation; the data were retrieved by field measurement, interview, and questionnaire. The data were analyzed in a quantitative manner with descriptive statistical analysis, scoring analysis, and qualitative descriptive analysis to result in the final evaluation score of the site's ecotourism potentials. The analysis result on the site's physical parameters (vegetation, environmental hygiene, materials, and water brightness) indicated that the Botutonuo beach has high potential. The same criteria were also given in other physical parameters that consisted of distance, facilities, accessibility, and site attractiveness. Moreover, high ecotourism potential was also shown by the site's other parameters (institutional, sociocultural, economic, and environmental parameters). The site's high ecotourism potential was due to the beach's characteristics. The site is a sandy beach that is naturally formed. On top of that, the community's contribution to constructing tourism facilities was influential in boosting the ecotourism potentials.
\end{abstract}

Key words: Botutonuo Beach, ecotourism, Geographic Information System

\section{INTRODUCTION}

Bone Bolango Regency is one of the regency in Gorontalo province, which has many tourism potentials. Its natural and cultural diversity are the capital for development of tourism attraction, source of local revenue and economic growth. Currently, only small part of these natural and cultural potentials are explored to attract local and foreign tourists (Correia et al., 2011; Canavan, 2016; Ministry of Tourism and Creative Economy, 2020). Locally, Gorontalo tourism potentials are supported with its morphological and geological structures, such as natural resources potentials, limestone distribution, and geological structure. The study of Botutonuo Beach ecotourism in the development of tourist attractions that rely more on its natural potential, it is necessary to have a geological study which includes all aspects that can be measured and analyzed in the field (Eraku et al., 2017; Permana et al., 2019a, Permana et al., 2019b; Eraku and Permana, 2020; Permana et al., 2020; Permana

\footnotetext{
* Corresponding author
} 
et al., 2021a; Permana et al., 2021b). Ecotourism is one of the alternative tourism considered as one of the ways to improve the economic life of rural communities because it is considered to be able to provide job opportunities, business opportunities, and increase the development of business skills (Scheyvens, 2000). Ecotourism will provide a greater opportunity to control the use of natural resources in certain areas as one of the assets of ecotourism activities (Ashley and Roe, 1997; Fennel, 1999; Fandeli and Muhklison, 2000; Fuller et al., 2005). The problem that has arisen at this time is that the development of ecotourism potential on Botutonuo Beach has not been maximized due to the influence of the Covid-19 pandemic which has affected the decrease in visitors. Whereas the benefits of ecotourism have an impact in various aspects including aspects of conservation, empowerment and environmental education (Stem et al., 2003; Vitasurya, 2015).

The coastal area of Bone Bolango regency is potential to be developed as ecotourism sites. Ecotourism states that ecotourism is a responsible natural tourism in the local area, which takes into account environmental education, environmental awareness, and supports natural conservation efforts, and increases local income (Regulation of the Minister of Home Affairs Number 33 of 2009). In addition, the main target of this ecotourism is to integrate conservation efforts, community, and sustainable development (Ghorbani et al., 2015). These are things that should be considered in planning and development of ecotourism industry (Motlagh et al., 2020). Ecotourism offers the balance of integrated tourism values between enjoying the nature and preserving it. It is an important element of sustainable tourism (Haryanto, 2014; Hijriati and Mardiana, 2014; Motlagh et al., 2020). This ecotourism provides solution for tourism development problems. Ecotourism development brings social, economic, and environmental benefits of natural resources utilization and has direct impact on the increase of local revenue. This study expands the social capital that encourages collective action of citizens for rural tourism development. The data obtained can be through face-to-face interviews with community leaders and structured questionnaires with residents (Zambrano et al., 2010; Nyaupane and Poudel, 2011; Liu et al., 2014).

Botutonuo beach is a highly potential site for ecotourism in Gorontalo and its surrounding area. This beach has a long white sandy beach and a beautiful mountain view as its backdrop. These natural resources advantages are potentials to be developed as an ecotourism site. Through ecotourism, community is expected to be able to utilize this natural, cultural, and historical potential without having $\mathrm{t}$ destroy or sell them. This carrying capacity concept is developed to minimize the destruction or degradation of natural resources, hence, the preservation, the existence, and the function of the nature can be achieved, and at the same time community, as user of this natural resources also gain benefits (WWF, 2009; Yulianingsih, 2010). This tourism destination is developed synergically with amenities, public facilities, accessibilities, and community empowerment in sustainable and integrated ways (Ministry of Tourism and Creative Economy, 2020). Therefore, an analysis of ecotourism potentials is important to be carried out as currently there is no research on ecotourism potentials in Botutonuo Beach site. Hence, this research aims at analyzing the ecotourism potentials of the Botutonuo beach based on its physical parameters of socio-cultural, economic, and institutional parameters (Asrul, 2017). The hope of this research was that the parameters, methods and analysis used can complement each other to produce a clear understanding of the development of ecotourism on Botutonuo Beach. The parameters and methods used can be used as input for ecotourism research in other locations. The main objective of this research is to analyze the ecotourism potential of Botutonuo Beach using the Geographic Information System (GIS).

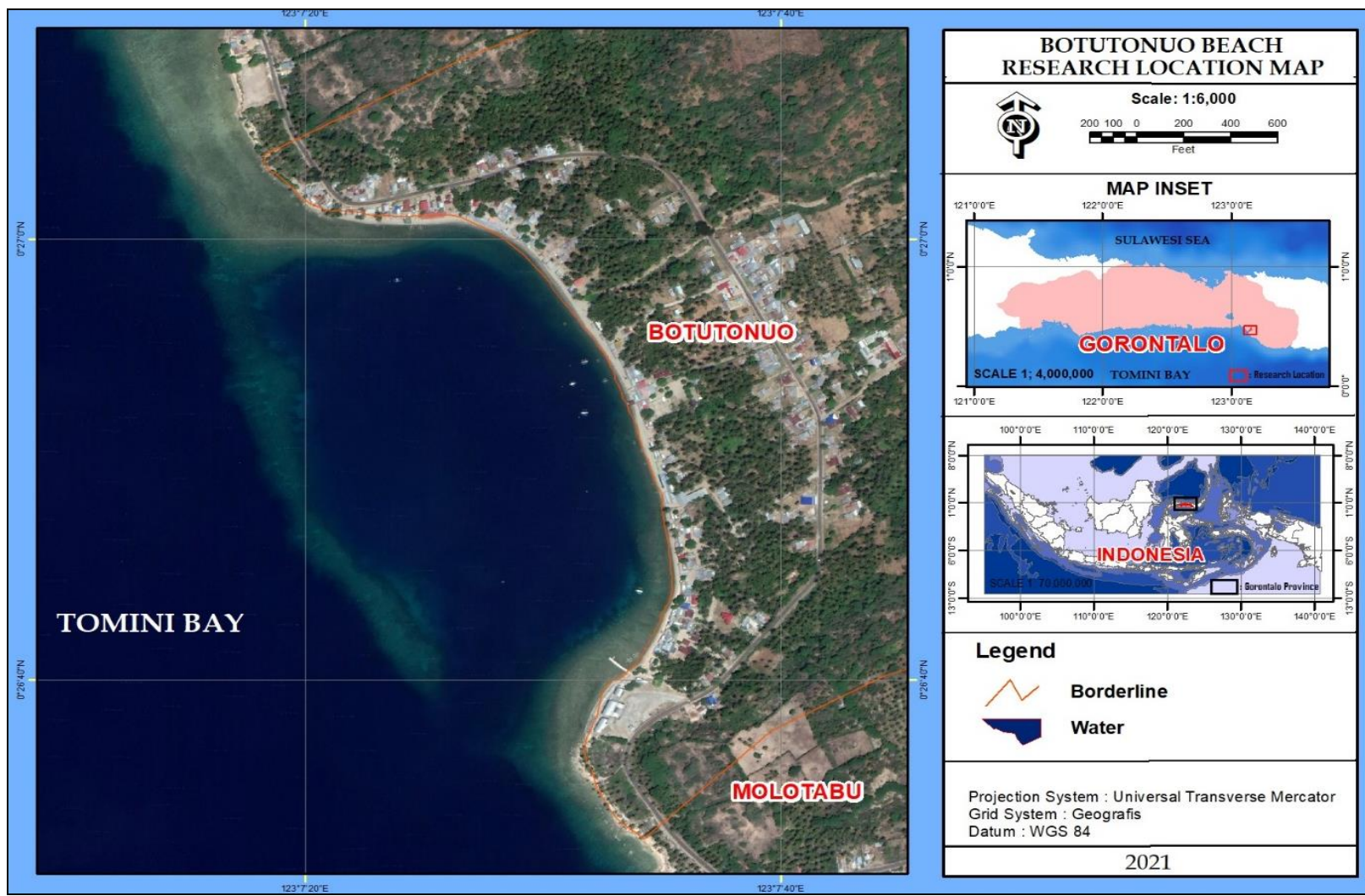

Figure 1. Research location map of Botutonuo Beach of Bone Bolango Regency (Source: Quickbird Image SAS Planet, 2020) 


\section{MATERIALS AND METHODS}

Botutonuo is a coastal village in Bone Bolango Regency, which has beach tourism potential. It is located in Kabila Bone district of Bone Bolango regency. Based on the village potential data, it is noted that the village stretch in an area of \pm 3100 $\mathrm{Km}^{2}$ see Figure 1. It is situated in the northern hill side of Bone Bolango Regency. In the north, the border is the Suwawa district; in the south, the border is Tomini Bay; whereas in the east, the border is Bone Pantai District; and the west border is Botupingge district. Morphologically, large proportion of this village consists of hill side and low land area. Botutonuo village consists of four hamlets: Botutonuo Timur, Botutonuo Barat, Pancuran and Bunga hamlet. This research employs spatial ecological approach with Geographical Information System (GIS) (Bunruamkaew and Murayama, 2011). Data collected in this study are primary and secondary data, where primary data are collected through observation method (directly taken from the field), interview, and distribution of questionnaire. Whereas, secondary data are obtained from interview with related stakeholders and literature review. Quantitative analysis is also employed in this study, in which descriptive statistic method is used to interpret the feedback of the questionnaires, and scoring analysis for physical parameters, and descriptive qualitative analysis for final appraisal of ecotourism potentials of Botutonuo Beach (Pramudya, 2008; Asrul, 2017).

\section{A. Data Collection}

The potential appraisal for a tourism object is carried out based on its physical parameters by quantifying the value of each parameters with its quality. The results of each parameters then combined to form a total result for physical parameters of ecotourism potentials. The parameters are made up of distance, infrastructure, accessibility, attraction and availability of fresh water see Table 1.

Information:
PP : Physical Parameter
WV : Weight Value
D : Distance
I : Infrastructure
Ac : Accessibility
At : Attraction
AFW: Availability of Fresh Water

Table 1. Tourism Criteria Based on Physical Parameters (PP) Source: (Gunn modified model, 1979 in Asrul, 2017)

\begin{tabular}{|c|c|c|c|c|c|c|}
\hline \multirow{2}{*}{ No } & \multirow{2}{*}{ Parameter } & \multicolumn{5}{|c|}{ Potential Value } \\
\hline & & Very Weak (1) & Weak (2) & Moderate (3) & Strong (4) & Very Strong (5) \\
\hline 1 & Distance (D) & $>60 \mathrm{~km}$ & $44.01-60 \mathrm{~km}$ & $30.01-45 \mathrm{~km}$ & $15.01-30 \mathrm{~km}$ & $>15 \mathrm{~km}$ \\
\hline 2 & $\begin{array}{l}\text { Infrastructure } \\
\text { (I) }\end{array}$ & \begin{tabular}{|l} 
No infrastructure \\
available within the \\
radius of $1 \mathrm{~km}$
\end{tabular} & \begin{tabular}{|l} 
Infrastructure are \\
available within the \\
radius of $1 \mathrm{~km}$
\end{tabular} & \begin{tabular}{|l|} 
There are $2-3$ \\
infrastructure available \\
within the radius of $1 \mathrm{~km}$
\end{tabular} & $\begin{array}{l}\text { There are } 4 \text { types of } \\
\text { infrastructure within } \\
\text { the radius of } 1 \mathrm{~km}\end{array}$ & $\begin{array}{l}\text { There are }>4 \text { types of } \\
\text { infrastructure within } \\
\text { the radius of } 1 \mathrm{~km}\end{array}$ \\
\hline 3 & $\begin{array}{l}\text { Accessibility } \\
(\mathrm{Ac})\end{array}$ & $\begin{array}{l}>1,000 \mathrm{~m} \text { from the } \\
\text { main road }\end{array}$ & $\begin{array}{l}500-1,000 \mathrm{~m} \text { from the } \\
\text { main road }\end{array}$ & $\begin{array}{l}<500 \mathrm{~m} \text { from the main } \\
\text { road }\end{array}$ & $\begin{array}{l}<500 \mathrm{~m} \text { the main } \\
\text { street }\end{array}$ & $\begin{array}{l}<500 \mathrm{~m} \text { from the } \\
\text { main avenue }\end{array}$ \\
\hline 4 & $\begin{array}{l}\text { Attractions } \\
\quad(\mathrm{At})\end{array}$ & $\begin{array}{l}\text { There are }>3 \text { similar } \\
\text { attractions within the } \\
\text { radius of } 1 \mathrm{~km}\end{array}$ & $\begin{array}{l}\text { There are } 3 \text { similar } \\
\text { attraction within the } \\
\text { radius of } 1 \mathrm{~km}\end{array}$ & $\begin{array}{l}\text { There are } 2 \text { similar } \\
\text { attraction within the } \\
\text { radius of } 1 \mathrm{~km}\end{array}$ & $\begin{array}{l}\text { There is } 1 \text { similar } \\
\text { attraction within the } \\
\text { radius of } 1 \mathrm{~km}\end{array}$ & $\begin{array}{l}\text { There is no similar } \\
\text { attraction within the } \\
\text { radius of } 1 \mathrm{~km}\end{array}$ \\
\hline 5 & $\begin{array}{c}\text { Availability } \\
\text { of Fresh } \\
\text { Water (AFW) }\end{array}$ & $\begin{array}{l}\text { The distance between } \\
\text { the water source and } \\
\text { the site is }>4 \mathrm{~km}\end{array}$ & $\begin{array}{l}\text { The distance between } \\
\text { the water source and } \\
\text { the site is }>3.1-4 \mathrm{~km}\end{array}$ & $\begin{array}{l}\text { The distance between } \\
\text { the water source and the } \\
\text { site is } 2.1-3 \mathrm{~km}\end{array}$ & $\begin{array}{l}\text { The distance between } \\
\text { the water source and } \\
\text { the site is } 1.1-2 \mathrm{~km} \mathrm{~km}\end{array}$ & $\begin{array}{l}\text { The distance between } \\
\text { the water source and } \\
\text { the site is } 0-1 \mathrm{~km}\end{array}$ \\
\hline
\end{tabular}

The natural and cultural tourism potential assessment is based on institutional parameter, socio-cultural parameter, and economic and environment parameter. The method to determine the scoring value for ISCEP is similar to those of physical parameter (PP), where each institutional parameter, social parameter, cultural parameter, and environmental parameter (ISCEP) are multiplied with the quality of the parameter, and totaled using the scoring formula listed below. The parameters are made up of management, attraction, security, food and souvenir stalls and spatial arrangement Table 2.
Information:
WV: Weight Value
M : Management
At : Attraction
$S$ : Security
FSS: Food and Souvenir Stalls
SA : Spatial Arrangement

Table 2. Tourism Criteria based on Institutional, Social, Cultural, and

Environment Parameters (ISCEP) (Source: Gunn, 1979 modified model in Asrul, 2017)

\begin{tabular}{|c|c|l|l|l|}
\hline \multirow{2}{*}{ No } & \multirow{2}{*}{ Parameter } & \multicolumn{2}{|c|}{ Potential Value } \\
\cline { 2 - 5 } & Management (M) & Management unavailable & Moderate (2) & \multicolumn{1}{c|}{ Very Strong (3) } \\
\hline 1 & Attraction (At) & No tourism attraction available & Attraction available1 - 2 months & Attraction available > 2 months \\
\hline 2 & Security (S) & Security personnel not available & & Security personnel available \\
\hline 4 & $\begin{array}{c}\text { Food and Souvenir Stall } \\
\text { (FSS) }\end{array}$ & No food and souvenir stalls available & $1-5$ food and souvenir stalls available & $\begin{array}{l}\text { More than 5 food and souvenir } \\
\text { stalls available }\end{array}$ \\
\hline 5 & Spatial Arrangement (SA) & Not in accordance with spatial planning & & In accordance with spatial planning \\
\hline
\end{tabular}




\section{B. Data Analysis}

Data analysis to assess the potential value of an ecotourism obtained through average score of physical parameters (PP) and socio-cultural, economic and environment institutional (ISCEP) combination (Pramudya, 2008; Asrul, 2017).

$$
\text { Tourism Potential Score }(\mathrm{TPS})=\frac{\sum P P+\sum I S C E P}{2} \quad \text { Class Interval } \frac{\sum \text { maxscore }- \text { min } \sum \text { gcore }}{\sum \text { criteria }}
$$

Then the score is entered into the assessment classification (Table 3) as tourism potential from very low potential to very high potential with an interval of suitability classes determined by the formula (Walpole, 1982).

Table 3. Tourism Potential Assessment Classification (Walpole, 1982)

\begin{tabular}{|l|l|l|}
\hline No & Total Score & Information \\
\hline 1 & $1-2$ & Low Potential \\
\hline 2 & $2.01-3$ & Moderate Potential \\
\hline 3 & $3.01-4$ & High Potential \\
\hline 4 & $4.01-5$ & Very High Potential \\
\hline
\end{tabular}

\section{RESULTS AND DISCUSSION}

\section{A. Physical Parameter (PP) Scoring Method}

Determining the potential value of a tourist attraction based on physical parameters (PP) is done by multiplying the value of each parameter by the weight value of a parameter. After obtaining the results of the operation, the values of the physical parameters of the object being analyzed are summarized. The results of the score calculation from the physical parameters (PP) can be seen in Table 4.

$$
\begin{aligned}
& \mathbf{P P}=(\mathbf{W V} \times \mathbf{D})+(\mathbf{W V} \times \mathbf{I})+(\mathrm{WV} \times \mathbf{A c})+(\mathbf{W V} \times \mathbf{A t})+(\mathbf{W V} \times \mathbf{A F W}) \\
& \mathbf{P P}=(\mathbf{0 . 3} \times \mathbf{4})+(\mathbf{0 . 2} \times \mathbf{4})+(\mathbf{0 . 2} \times \mathbf{4})+(\mathbf{0 . 2} \times \mathbf{3})+(\mathbf{0 . 1} \times \mathbf{3}) \\
& \mathbf{P P}=\mathbf{1 . 2}+\mathbf{0 . 8}+\mathbf{0 . 8}+\mathbf{0 . 6}+\mathbf{0 . 3}=\mathbf{3 . 7} \\
& \text { Note: } \text { a. Weight values have been determined based on parameters (Gunn, 1979) } \\
& \quad \text { c. The potential value is determined based on the results of the research location survey } \\
& \quad \text { d. Final score is determined based on the multiplication of weights and scores }
\end{aligned}
$$

\section{B. Institutional, Social, Cultural, and Environment Parameters (ISCEP) Scoring Method}

Determining the potential value of a tourism object based on the socio-economic and cultural institutional parameters (ISCEP) is done by multiplying the value of each parameter by the weight value of a parameter. After obtaining the results of the operation, the ISCEP values of the analyzed objects are summed. The results of the score calculation from the socioeconomic and cultural institutional parameters (ISCEP) can be seen in Table 5.

Table 4. Tourism Criteria Based on

Physical Parameters at Botutonuo Beach

\begin{tabular}{|c|l|c|c|}
\hline No & \multicolumn{1}{|c|}{ Parameters } & $\begin{array}{c}\text { Weight Value } \\
(\mathbf{W V})\end{array}$ & $\begin{array}{c}\text { Potential } \\
\text { Value }\end{array}$ \\
\hline 1 & Distance (D) & 0.3 & 4 \\
\hline 2 & Infrastructure (I) & 0.2 & 4 \\
\hline 3 & Accessibility (Ac) & 0.2 & 4 \\
\hline 4 & Attractions (At) & 0.2 & 3 \\
\hline 5 & Availability of Fresh Water. (AFW) & 0.1 & 3 \\
\hline \multicolumn{2}{|c|}{ Total } & $\mathbf{1}$ & \\
\hline
\end{tabular}

Table 5. Tourism Criteria based on Institutional, Social, Cultural, and Environment Parameters (ISCEP) at Botutonuo Beach

\begin{tabular}{|c|l|c|c|}
\hline No & \multicolumn{1}{|c|}{ Parameters } & $\begin{array}{c}\text { Weight Value } \\
\text { (WV) }\end{array}$ & $\begin{array}{c}\text { Potential } \\
\text { Value }\end{array}$ \\
\hline 1 & Management (M) & 0.2 & 3 \\
\hline 2 & Attraction (At) & 0.1 & 3 \\
\hline 3 & Security (S) & 0.3 & 3 \\
\hline 4 & Food and Souvenir Stall (FSS) & 0.1 & 1 \\
\hline 5 & Spatial Arrangement (SA) & 0.3 & 3 \\
\hline \multicolumn{2}{|c|}{ Total } & $\mathbf{1}$ & \\
\hline
\end{tabular}

\footnotetext{
ISCEP $=(\mathbf{W V} \times \mathbf{M})+(\mathbf{W V} \times \mathbf{A t})+(\mathbf{W V} \times \mathbf{S})+(\mathbf{W V} \times \mathbf{F S S})+(\mathbf{W V} \times \mathbf{S A})$

ISCEP $=(0.2 \times 3)+(0.1 \times 3)+(0.3 \times 3)+(0.1 \times 1)+(0.3 \times 3)$

$\mathrm{ISCEP}=0.6+0.3+0.9+0.1+0.9=2.8$
}

Note: a. Weight values have been determined based on parameters (Gunn, 1979)

c. The potential value is determined based on the results of the research location survey

d. Final score is determined based on the multiplication of weights and scores

\section{Tourism Potential Scoring Method}

The tourism potential scoring of Botutonuo Beach is determined by calculating the average value of the final value of tourism objects from the two assessment groups, namely Physical Parameter (PP) Scoring Method and Institutional, Social, Cultural, and Environment Parameters (ISCEP) Scoring Method.

TPS $=\frac{\Sigma \text { Pf }+\Sigma P K S E L}{2}=\frac{3.7+2.8}{2}=3.25($ High Potential $)$

\section{Analysis of Ecotourism for Botutonuo Beach}

Botutonuo beach is located in Kabila Bone District of Bone Bolango regency. Beach vegetation is a vegetative group that grow in intertidal area up to the land area that still receive influence form the sea. The vegetation in Botutonuo beach area are Cocos nucifera tree and Terminalia catappa tree. There are also well-preserved white sandy beach filled with sand, pebbles, and medium size stones. The strong wind and sea waves bring small particles of corals and other materials to the beach. The water in this area is very clear. Thus, it is suitable for swimming, diving, rowing and fishing. This beach area is also clean and the local community maintains the cleanliness in this area. Based on the analysis of physical parameters of the beach, which consists of vegetation, environmental hygiene, beach materials and water brightness, the Botutonuo beach is highly potential to be developed.

Botutonuo beach located about $22.83 \mathrm{~km}$ from the capital city of Bone Bolango regency and can be reached in about 30 minutes using two and four-wheeled vehicles. The distance is measured by gusing the length of the road from the capital city 
of the regency to a tourism site in each regency. This measurement is carried out using the shortest route tool within the Quantum GIS software. This tool requires the coordinate point of the initial location and the destination measured from the capital of the regency to the coordinate point of the ecotourism site. The accessibility to this tourism site is also quite good due to the availability of the paved road. The Botutonuo beach has been managed by the local community as a tourism site since early 2000s. The local community have cooperated to build several gazebos for the tourists to sit and place their belongings. From its initial establishment in 2000 to 2002, the gazebos' roofs were made of thatch roofs. In 2003, the local community collectively changes the roofs to tin roofs. Within the radius of one $\mathrm{km}$, the available amenities are cottages, mosque, and health care center. In addition, within the area, the amenities are tire floaters, small boats for rent, and gazebos.

Based on the attraction parameter, the tourism site assessment is carried out by creating a buffer of one km for each tourism object and tourism site type within this buffer area is identified. Based on the assessment result of the ecotourism potentials of the Botutonuo beach, it is categorized as high potential due to various ecotourism activities that can be done within this site. Those activities are: swimming, boating, snorkeling, diving, fishing, and other beach sports and fun activities. The availability of clean fresh water in this area is also important for rinsing and other cleaning purposes. The clean and fresh water source is available within the radius of one km of the tourism site, thus it strongly supports the development of beach ecotourism.

Most of the tourists in Botutonuo beach are local visitors from Bone Bolango regency, Gorontalo municipality, and Gorontalo regency. They come in groups, either family groups, school groups, government institution groups, and youth groups. The assessment based on the institutional, socio-cultural, economic, and environment parameters are strongly supportive. This is due to the natural development of this tourism site as the community themselves initiate the development of this site by building the tourism facilities to support this site attraction as well as for their source of income.

Therefore, the management of this site tend to be collectively managed by the community. Administratively, Botutonuo beach is under the management of the Tourism and Creative Economy Department of Bone Bolango regency. Local community's involvement in the management of this tourism attraction are mostly as merchants, parking lot management, and cottage owners. In addition to natural attraction in this area, the tourists can also enjoy the unique experience of traditional fishermen's lives. In this area, tourists can see fishermen activities, from fishing, to selling their catch in the fish market, and enjoying the traditional culinary made of local fishermen catch. These can attract tourists to come to Botutonuo. The tourism development activities within this site is beneficial for the community in this area. Based on the final scoring of the physical parameters and institutional, social, economic, and environmental parameters, it is revealed that the Botutonuo beach is highly potential. The community are utilizing the intact natural beauty, cultural dan history values of the local people. Botutonuo Village originated from the name of a hamlet originating from the main village of Molotabu. It was named Botutonuo because in ancient times there was a Tobelo kingdom, which reportedly said that Tobelo was a man-eating man. They were expelled from the village of Bune and then they ran to the coast, it is said that during the escape they stopped and lived temporarily in a large rock in this village to release tired before continuing the journey to the eastern part of the coast. In the local language of Gorontalo, a stopover and temporary stay is called "Loti Tonuo" and by the previous people who opened this village, the stone which became a place to stop and live temporarily by the Tobelo people was called Botutonuo which was later used as the name of this village, namely "Botutonuo". Botutonuo was opened in the 1600 s when it was still a wilderness filled with thickets (Botutonuo Village Profile, 2012). The beautiful natural view, underwater site of snorkeling and diving, culinary tourism, and the site attraction have made this site to have abundant tourism potentials to be developed.

This tourism site also contributes to the income of local community. Large number of visitors will ensure higher income for local community, and in turn, will have positive impact on their livelihoods. Based on the results of interviews with the Abdullah Gaib community as well as the manager of the Botutonuo Beach tourist attraction, this coastal ecotourism area was managed by the community as a tourist spot before 2000. The community worked together to build several gazebos as tourist attractions. Since the beginning of construction until 2002, the gazebo still uses a thatched roof, after 2003 the community raised funds and replaced the roof with zinc. The facilities and infrastructure available at Botutonuo Beach within a radius of 1 $\mathrm{km}$ are lodging, houses of worship and health facilities in the form of a health center. The same thing was conveyed by other people, namely Aus Kamba, various facilities that can be enjoyed in the form of swimming tires for playing water, boat rentals and shelter (gazebo). The income earned from renting swimming tires, renting boats and gazebos can meet the needs of his family.

\section{CONCLUSION}

Botutonuo beach is a highly potential site. This is based on the physical parameters analysis of the beach: its vegetation, environmental hygiene, beach materials, and water clarity. Similar result is also obtained from the physical parameters of distance, amenities, accessibilities, and attractiveness of this site. In addition, the institutional, socio-cultural, economic, and environment parameters also yield similar result. In addition, the community participation in developing the tourism facilities also serve as additional value for the development of ecotourism in Botutonuo beach. The local community utilize the intact and beautiful natural view, its culture and history without having to destroy or to sell them. The natural view potential, underwater attraction for snorkelling and diving, culinary tourism, and recreational site have made this site to have diverse tourism resources. This potential can be developed to support the local economy and increase the welfare of the people in this area.

\section{REFERENCES}

Ashley, C., \& Roe, D. (1997). Community involvement in wildlife tourism: strengths, weaknesses and challenges. London: Evaluating Eden Project, International Institute for Environment and Development, 39.

Asrul (2017). Pemetaan potensi pariwisata alam di Kabupaten Bone Bolango menggunakan system informasi geografi [Mapping the potential for natural tourism in Bone Bolango Regency using a Geographic Information System]. Skripsi Universitas Negeri Gorontalo, Not publicly published. 
Bunruamkaew, K., \& Murayama, Y. (2011). Site suitability evaluation for ecotourism using GIS \& AHP: A case study of surat Thani Province, Thailand. Procedia - Social and Behavioral Sciences, 21, 269-278. https://doi.org/10.1016/j.sbspro.2011.07.024

Canavan, B. (2016). Tourism culture: nexus, characteristics, context and sustainability. Tourism Management, 53, 229-243, http://dx.doi.org/10.1016/j.tourman.2015.10.002

Correia, A., Kozak, M., \& Ferradeira, J. (2011). Impact of culture on tourist decision-making styles. International Journal of Tourism Research, 13, 433-446. https://doi.org/10.1002/jtr.817

Eraku, S.S., Permana, A.P., \& Hulukati, E. (2017). Potensi sumber daya alam fosil kayu di daerah Gorontalo [Natural wood fossil resources potential in Gorontalo]. Jurnal Pengelolaan Sumber Daya Alam dan Lingkungan, 7(2), 172-177, (in Indonesian). https://doi.org/10.29244/jpsl.7.2.172-177

Eraku, S.S., \& Permana, A.P. (2020). Erosion hazard analysis in the Limboto lake catchement area, Gorontalo Province, Indonesia. News of the National Academy of Sciences of the Republic of Kazakhstan, Series of Geology and Technical Sciences. 3 (441), 110-116. http://dx.doi.org/10.32014/2020.2518-170X.61

Fandeli, C., \& Muhklison (2000). Pengusahaan ekowisata [Ecotourism business]. Fakultas Kehutanan. Yogyakarta: Universitas Gadjah Mada.

Fennel, D.A. (1999). Ecotourism: An Introduction. London: Routledge, 315.

Fuller, D., Buultjens, J., \& Cummings, E. (2005). Ecotourism and indigenous micro-enterprise formation in northern Australia opportunities and constraints. Tourism Management, 26(6), 891-904. http://dx.doi.org/10.1016/j.tourman.2004.04.006

Ghorbani, A., Raufirad, V., Rafiaani, P., \& Azadi, H. (2015). Ecotourism sustainable development strategies using SWOT and QSPM model: A case study of Kaji Namakzar Wetland, South Khorasan Province, Iran. Tourism Management Perspectives, 16, $290-297$. http://dx.doi.org/10.1016/j.tmp.2015.09.005

Haryanto, J.T. (2014). Model pengembangan ekowisata dalam mendukung kemandirian ekonomi daerah studi kasus Provinsi DIY [Model of ecotourism development in support of regional economic independence. Case study of Yogyakarta Province]. Jurnal Kawistara, 4(3), 225-330. https://doi.org/10.22146/kawistara.6383

Hijriati, E., \& Mardiana, R. (2014). Pengaruh ekowisata berbasis masyarakat terhadap perubahan kondisi ekologi, sosial dan ekonomi di Kampung Batusuhunan, Sukabumi [The effect of community-based ecotourism on changes in ecological, social and economic conditions in Batusuhunan Village, Sukabumi]. Jurnal Sosiologi Pedesaan, 2(3), 146-159, (in Indonesia). https://doi.org/10.22500/SODALITY.V2I3.9422

Liu, J., Qu, H., Huang, D., Chen, G., Yue, X., Zhao, X., \& Liang, Z. (2014). The role of social capital in encouraging residents' pro-environmental behaviors in community-based ecotourism. Tourism Management, 41, 190-201. https://doi.org/10.1016/J.TOURMAN.2013.08.016

Nyaupane, G.P., \& Poudel, S. (2011). Linkages among biodiversity, livelihood, and tourism. Annals of Tourism Research, 38(4), $1344-1366$. https://doi.org/10.1016/j.annals.2011.03.006

Permana, A.P., Pramumijoyo, S., \& Akmaluddin. (2019a). Uplift rate of Gorontalo limestone (Indonesia) based on biostratigraphy analysis . News of the National Academy of Sciences of the Republic of Kazakhstan, Series of Geology and Technical Sciences, 6 (438), 6-11. https://doi.org/10.32014/2019.2518-170X.150

Permana, A.P., Pramumijoyo, S., \& Akmaluddin (2019b). Analysis of microfacies and depositional environment of limestone in Yosonegoro area, Gorontalo Province, Indonesia. Bulletin of the Iraq Natural History Museum, 15 (4), 443-454. https://doi.org/10.26842/binhm.7.2019.15.4.0443

Permana, A.P., Pramumijoyo, S., \& Akmaluddin. (2020). Paleobathymetry analysis of limestone in Bongomeme region based on content of benthic foraminifera fossil, Gorontalo District, Indonesia. Bulletin of the Iraq Natural History Museum, 16 (1), 1-14. https://doi.org/10.26842/binhm.7.2020.16.1.0001

Permana, A.P., Pramumijoyo, S., Akmaluddin, \& Barianto, D.H. (2021a). Planktonic foraminiferal biostratigraphy of the Limboto limestone, Gorontalo Province, Indonesia. Kuwait Journal of Science, 48 (1), 116-126. https://doi.org/10.48129/kjs.v48i1.691 6

Permana, A.P., Pramumijoyo, S., \& Eraku, S.S. (2021b). Micorfacies and depositional environment of tertiary limestone, Gorontalo Province, Indonesia. News of the National Academy of Sciences of the Republic of Kazakhstan, Series of Geology and Technical Sciences, 2 (446), 15-21. https://doi.org/10.32014/2021.2518-170X.29

Pramudya, E. (2008). Evaluasi potensi obyek wisata aktual di Kabupaten Agam Sumatera Barat untuk perencanaan program pengembangan [Evaluation of the potential of actual tourism objects in Agam Regency, West Sumatra for development program planning]. Sekolah Pascasarjana Institut Pertanian Bogor.

Scheyvens, R. (2000). Promoting women's empowerment through involvement in ecotourism: experiences from the third world. Journal of Sustainable Tourism, 8(3), 232-249. http://dx.doi.org/10.1080/09669580008667360

Stem, C.J., Lassoie, J.P., Lee, D.R., \& Deshler, D.J. (2003). How 'eco' is ecotourism? a comparative case study of ecotourism in Costa Rica. Journal of Sustainable Tourism, 11(4), 322-347. https://doi.org/10.1080/09669580308667210

Vitasurya, V.R. (2015). Local wisdom for sustainable development of rural tourism, case on Kalibiru and Lopati Village, Province of Daerah Istimewa Yogyakarta. Social and Behavioral Sciences, 216, 97-108. https://doi.org/10.1016/j.sbspro.2015.12.014

Walpole, R.E. (1982). Pengantar statistik [Introduction to statistics]. PT Gramedia Pustaka Utama. Jakarta, 515.

Yulianingsih, T. (2010). Jelajah wisata nusantara beragam pilihan tujuan wisata di 33 provinsi [Explore archipelago tourism various options of tourist destinations in 33 provinces]. MedPress Publisher, Yogyakarta, 428.

Zambrano, A.M.A., Broadbent, E.N., \& Durham, W.H. (2010). Social and environmental effects of ecotourism in the Osa Peninsula of Costa Rica: The Lapa Rios case. Journal of Ecotourism, 9(1), 62-83. https://doi.org/10.1080/14724040902953076

*** Ministry of Tourism and Creative Economy. (2020). Dokumen rencana strategis Kementerian Pariwisata dan Ekonomi Kreatif/Badan Pariwisata dan Ekonomi Kreatif tahun 2020 - 2024 [Strategic plan document of the Ministry of Tourism and Creative Economy $/$ Tourism and Creative Economy Agency 2020-2024]. Jakarta.

*** Regulation of the Minister of Home Affairs Number 33 of 2009 tentang Pedoman pengembangan ekowisata di daerah [Concerning guidelines for developing ecotourism in the regions].

*** Botutonuo Village Profile. (2012). Sejarah asal usul Desa Botutonuo [History of the origins of Botutonuo Village]. Kabila Bone. Gorontalo, 18.

*** World Wildlife Fund (WWF). (2009). Prinsip dan kriteria ekowisata berbasis masyarakat [Principles and criteria for community based ecotourism]. Departemen Kebudayaan dan Pariwisata dan WWF, Indonesia.

Article history: Received: 07.12.2020 Revised: 08.04.2021 Accepted: 08.06.2021 Available online: 30.06 .2021 